\title{
Glycolytic, Krebs cycle and pentose phosphate cycle enzymes in spermatozoa of the buffalo (Bubalus bubalis)
}

\author{
K. S. Sidhu and S. S. Guraya \\ Department of Zoology, College of Basic Sciences \& Humanities, \\ Punjab Agricultural University, Ludhiana, India
}

\begin{abstract}
Summary. Various enzymes of glycolysis (hexokinase, phosphoglucoisomerase, aldolase and lactate dehydrogenase), the Krebs cycle (isocitrate, succinic and malate dehydrogenases), and the pentose phosphate cycle (glucose-6-phosphate and 6phosphogluconate dehydrogenases) were studied in buffalo spermatozoa by biochemical and cytochemical methods. The enzymes of glycolysis were found to be loosely bound whereas those of the Krebs and pentose phosphate cycles were strongly bound to mitochondrial membranes. All the enzymes studied were localized histochemically in the mid-piece.
\end{abstract}

\section{Introduction}

Glycolysis and respiration constitute the main sources of energy for motility in mammalian spermatozoa but the involvement of the pentose phosphate cycle in energy production is not confirmed (Wu, Mckenzie, Fang \& Butts, 1959; Balogh \& Cohen, 1964; Mann, 1964; Bolton \& Linford, 1970). Although much work has been done on the metabolism by spermatozoa of a great number of substrates, and particularly on those of the glycolytic pathway, there has been relatively little study of the isolation and histochemical distribution of the enzymes involved in these metabolic events (Mohri, Mohri \& Ernster, 1964; Peterson \& Freund, 1970; Harrison, 1971; Mathur, 1971; Harrison \& White, 1972; Keyhani \& Storey, 1973; Storey \& Kayne, 1975). The present study was therefore undertaken to examine various enzymes of glycolysis and the Krebs and pentose phosphate cycles in buffalo spermatozoa.

\section{Materials and Methods}

Semen samples were collected by artificial vagina from 5 buffalo (Bubalus bubalis) bulls known to be fertile $\left(115 \times 10^{7}\right.$ spermatozoa $\left./ \mathrm{ml}\right)$. Small volumes $(2 \mathrm{ml})$ of semen were then centrifuged at $500 \mathrm{~g}$ and $10^{\circ} \mathrm{C}$ for $20 \mathrm{~min}$. The sperm pellets obtained were washed gently twice in KrebsRinger (Mann, 1964) and again centrifuged at $500 \mathrm{~g}$ and $10^{\circ} \mathrm{C}$ for $20 \mathrm{~min}$. The sperm pellets were dispersed in $2 \mathrm{ml} \mathrm{Krebs-Ringer} \mathrm{and} \mathrm{dissociated} \mathrm{in} \mathrm{an} \mathrm{ultrasonic} \mathrm{processor} \mathrm{(VPL-}{ }_{2}$ model: Vibronic Private Ltd, Bombay, India) at a speed of 25000 shock waves/sec and power level of $120 \mathrm{~W}$ for $3 \mathrm{~min}$ in an ice-cold bath. The homogenates were centrifuged at $7300 \mathrm{~g}$ for $20 \mathrm{~min}$ at $4^{\circ} \mathrm{C}$. The supernatants were used for enzyme assays while the pellets were dispersed and incubated for $30 \mathrm{~min}$ at $37^{\circ} \mathrm{C}$ in a detergent mixture $(0.075 \%$ hyamine $+0.075 \%$ Triton-X 100 $(1: 1 \mathrm{v} / \mathrm{v})$ in $0.067 \mathrm{M}$-Tris-maleate buffer, $\mathrm{pH} 8.6)$. The suspensions were again sonicated for 3 min in an ice-cold bath and the homogenates were centrifuged at $7300 \mathrm{~g}$ for $20 \mathrm{~min}$ at $4^{\circ} \mathrm{C}$. These supernatants were also used for enzyme assays to detect enzymes which had been bound to membranes and detached by the detergent treatment (Churg, Zaneveld \& Schumacher, 1974). The protein in each sample was estimated by the method of Lowry, Rosebrough, Farr \& Randall (1951). 


\section{Enzyme assays}

Fractions were assayed for hexokinase (EC 2.7.1.1) according to the method of Slein, Cori \& Cori (1950), phosphoglucoisomerase (EC 5.3.1.9) according to the method of King (1964) and aldolase (EC 4.1.2.13) according to the method of Sibley \& Lehninger (1953) as cited by King (1964). Lactate dehydrogenase (EC 1.1.1.27), isocitric dehydrogenase (EC 1.1.1.42), succinic dehydrogenase (EC 1.3.99.1), malate dehydrogenase (EC 1.1.1.37), glucose-6phosphate dehydrogenase (EC 1.1.1.49) and 6-phosphogluconate dehydrogenase (EC 1.1.1.43) were estimated by the methods described previously by Sidhu \& Guraya (1978). All assays were performed in triplicate at $37^{\circ} \mathrm{C}$. One unit of enzyme activity represented $\mu \mathrm{mol}$ substrate/min under the specified assay conditions.

\section{Enzyme cytochemistry}

Smears of the washed semen were prepared and were subjected to cytochemical tests for aldolase and lactate, malate, isocitric, succinic, glucose-6-phosphate and 6-phosphogluconate dehydrogenases as described by Pearse (1961).

\section{Results}

The values for extractable protein and various enzymes after different treatments are given in Table 1.

Table 1. The activities (mean \pm s.e.m., $n=3$ ) of various enzymes in buffalo spermatozoa

\begin{tabular}{|c|c|c|c|}
\hline & \multicolumn{3}{|c|}{ Specific activities (units) } \\
\hline & $\begin{array}{l}\text { Sperm } \\
\text { sonicate }\end{array}$ & $\begin{array}{l}\text { Sperm sonicate } \\
\text { after incubation } \\
\text { in detergents }\end{array}$ & $\begin{array}{l}\text { Extractable } \\
\text { total }\end{array}$ \\
\hline Total protein $(\mathrm{mg} / \mathrm{ml})$ & $0.09 \pm 0.00$ & $0.18 \pm 0.00$ & $0.27 \pm 0.00$ \\
\hline \multicolumn{4}{|l|}{ Enzymes of glycolysis } \\
\hline Phosphoglucoisomerase & $6.92 \pm 0.92$ & $4.01 \pm 0.08$ & $12.93 \pm 1.00$ \\
\hline Aldolase & $142.48 \pm 2.37$ & $195.31 \pm 5.71$ & $337.79 \pm 7.98$ \\
\hline Lactate dehydrogenase & $30.0 \pm 1.11$ & $102.07 \pm 2.89$ & $132.07 \pm 4.00$ \\
\hline \multicolumn{4}{|l|}{ Enzymes of the Krebs cycle } \\
\hline Isocitric dehydrogenase & 0 & $66 \cdot 77 \pm 2 \cdot 81$ & $66 \cdot 77 \pm 2 \cdot 81$ \\
\hline Succinic dehydrogenase & $113.89 \pm 2.87$ & $199.62 \pm 3.87$ & $313.51 \pm 6.74$ \\
\hline Malate dehydrogenase & $12 \cdot 16 \pm 0.98$ & $151.53 \pm 2.02$ & $163.69 \pm 3.00$ \\
\hline \multicolumn{4}{|l|}{$\begin{array}{l}\text { Enzymes of the pentose } \\
\text { phosphate cycle }\end{array}$} \\
\hline $\begin{array}{l}\text { Glucose-6-phosphate } \\
\text { dehydrogenase }\end{array}$ & 0 & $41 \cdot 82 \pm 2 \cdot 83$ & $41 \cdot 82 \pm 2 \cdot 83$ \\
\hline $\begin{array}{l}\text { 6-Phosphogluconate } \\
\text { dehydrogenase }\end{array}$ & 0 & $121 \cdot 18 \pm 2 \cdot 81$ & $121 \cdot 18 \pm 2 \cdot 81$ \\
\hline
\end{tabular}

\section{Enzymes of glycolysis}

Most of the enzymes of glycolysis, such as hexokinase, phosphoglucoisomerase and aldolase, were readily extracted by sonication. However, lactate dehydrogenase was only slightly extracted with sonication. Detergent treatment of the sonicated residues resulted in some additional extraction, particularly of lactate dehydrogenase activity.

The histochemical tests revealed that aldolase and lactate dehydrogenase were present in the mid-piece, where a strong reaction was seen. 


\section{Enzymes of the Krebs cycle}

Isocitric, succinic and malate dehydrogenases were not readily extracted by sonication alone but detergent treatment caused further release of activity. Strong histochemical reactions were obtained in the sperm mid-piece for all 3 enzymes.

\section{Enzymes of the pentose phosphate cycle}

Glucose-6-phosphate and 6-phosphogluconate dehydrogenases were not extracted with sonication and activity was only obtained after detergent treatment followed by sonication. Both enzymes were localized histochemically in the mid-piece.

\section{Discussion}

Glycolysis is catalysed by the consecutive action of a group of 11 enzymes. Since they are easily extracted in soluble form from cells, they are believed to be localized in the soluble portion of the cytoplasm. There is evidence, however, that in different types of cells some of the enzymes of glycolysis may be loosely associated with the plasma membrane, with myofibrils, or with mitochondria (Lehninger, 1975). There are only a few reports that deal with the localization of glycolytic enzymes in spermatozoa (Harrison, 1971; Storey \& Kayne, 1975) and the previous results are controversial. The present study clearly demonstrates that the glycolytic enzymes in buffalo spermatozoa are exclusively present in the mitochondria of the mid-piece. From the extraction procedure used in the present study, it can be concluded that although most of the activity of the glycolytic enzymes is easily extracted and therefore loosely bound, some activity is more tightly bound to the sperm mid-piece (see Churg, Zaneveld \& Schumacher, 1974). Storey \& Kayne (1975) found that in rabbit spermatozoa 7 of the enzymes of the glycolytic pathway (i.e. aldolase, triosephosphate isomerase, glyceroldehyde phosphate dehydrogenase, 3phosphoglyceromutase, enolase, pyruvate kinase and lactate dehydrogenase) are bound strongly enough to resist removal by washing after treatment with hypotonic media.

Hexokinase is a rate-controlling enzyme in glycolysis (Walker, 1966) and in buffalo spermatozoa it is strongly bound to the mid-piece. Similar observations have also been made for bull, ram and boar spermatozoa (Morton, 1968; Harrison, 1971; Storey \& Kayne, 1975). Phosphoglucoisomerase, an enzyme of the second step of glycolysis, is loosely bound to the mitochondria of buffalo spermatozoa. It is a soluble enzyme and is readily extracted from the spermatozoa (Harrison, 1971; Storey \& Kayne, 1975). Over half of the aldolase activity is strongly bound to the mid-piece of buffalo spermatozoa. Its presence in the mid-piece of buffalo spermatozoa is confirmed by its histochemical localization. Similar observations have been made by Storey \& Kayne (1975) for rabbit spermatozoa. Aldolase activity has also been estimated biochemically in some previous studies on buffalo spermatozoa (Chauhan, 1973). Lactate dehydrogenase is strongly bound to the mid-piece of buffalo spermatozoa as found by previous workers for other species (Mann, 1964; Harrison, 1971; Mathur, 1971; Storey \& Kayne, 1975).

In contrast to the enzymes of glycolysis, those of the Krebs cycle are found in the mitochondrial fraction of the cell, mostly in the matrix in proximity to the respiratory enzymes (Harper, 1973). Isocitric, succinic and malate dehydrogenases in buffalo spermatozoa are strongly bound to the mid-piece. Succinic dehydrogenase has been estimated in buffalo (Edward \& Velantine, 1963; Ayyagari \& Mukherjee, 1970; Singh \& Sandhu, 1972) and rat, mouse and human (Rao, Sheth \& Phadke, 1959; Mathur, 1971) spermatozoa.

Glucose-6-phosphate and 6-phosphogluconate dehydrogenases, enzymes of the pentose phosphate cycle, are strongly bound to the membranes of the sperm mid-piece, as found by Bolton \& Linford (1970) for boar spermatozoa. Slight activity of glucose-6-phosphate dehydrogenase has also been reported for human, mouse, rat, guinea-pig, cat and dog 
spermatozoa (Balogh \& Cohen, 1964). In other animal cells, glucose-6-phosphate and 6phosphogluconate dehydrogenases are found in the extra-mitochondrial soluble portion and are involved in the direct oxidation of glucose to five carbon residues and generation of reduced NADP (see Harper, 1973). In spermatozoa, the evidence for direct oxidation of glucose by way of the pentose phosphate cycle is fragmentary (Wu et al., 1959), but the present findings indicate that the pentose phosphate cycle could be involved in the energy production of buffalo spermatozoa.

K.S.S. thanks the CSIR Government of India for a Senior Research Fellowship and a W.H.O. grant to S.S.G. under the small supplies programme is acknowledged.

\section{References}

Ayyagari, V.B. \& Mukherjee, D.P. (1970) Effect of adrenaline on succinic dehydrogenase activity and morphology of the mid-piece of mice spermatozoa. $J$. Reprod. Fert. 22, 375-378.

Balogh, K. \& Cohen, R.B. (1964) A cytochemical technique for studying oxidative enzyme systems of mammalian spermatozoa in semen smears. Fert. Steril. 15, 35-39.

Bolton, A.E. \& Linford, E. (1970) Presence of the dehydrogenases of the pentose phosphate pathway in boar spermatozoa. J. Reprod. Fert. 21, 353-354.

Chauhan, R.A.S. (1973) Studies on certain characteristics of buffalo semen. JNKVV Res. J. 6, 40-42.

Churg, A., Zaneveld, L.J.D. \& Schumacher, G.F.B. (1974) Detergent treatment of human and rabbit spermatozoa: ultrastructural changes and release of mid-piece enzymes. Biol. Reprod. 10, 429-437.

Edward, R.G. \& Velantine, R.C. (1963) Cytochemical demonstration of succinic dehydrogenase in intact rabbit spermatozoa. Expl Cell Res. 31, 508-516.

Harper, H.A. (1973) Review of Physiological Chemistry. Lange Medical Pub., Marugen Co. Ltd, Japan.

Harrison, R.A.P. (1971) Glycolytic enzymes in mammalian spermatozoa. Activities and stability of hexokinase and phosphofructokinase in various fractions from sperm homogenate. Biochem. J. 124, 741-750.

Harrison, R.A.P. \& White I.G. (1972) Glycolytic enzymes in the spermatozoa and cytoplasmic droplets of bull, boar and ram, and their leakage after shock. J. Reprod. Fert. 30, 105-115.

Keyhani, E. \& Storey, B.T. (1973) Oxidation rates of krebs cycle carboxylic acids by the mitochondria of hypotonically treated rabbit epididymal spermatozoa. Fert. Steril. 24, 864-871.

King, E.J. (1964) Practical Clinical Enzymology. Van Nostrand Co., London.

Lehninger, A.L. (1975) Biochemistry. The Molecular Basis of Cell Structure and Function. Worth Pub. Inc., New York.

Lowry, O.H., Rosebrough, N.J., Farr, A.L. \& Randall, R.J. (1951) Protein measurement with the Folin phenol reagent. J. biol. Chem. 193, 265-275.
Mann, T. (1964) The Biochemistry of Semen and of the Male Reproductive Tract. Methuen, London.

Mathur, R.S. (1971) Histo-enzymological observations on spermatozoa of inbred strains of mice. $J$. Reprod. Fert. 27, 5-11.

Mohri, H., Mohri, T. \& Ernster, L. (1964) Biochemical properties of bull sperm mitochondria. Biochem. $J$. 82, 32P.

Morton, B.E. (1968) A disruption and fractionation of bovine epididymal spermatozoa. J. Reprod. Fert. 15, 113-119.

Pearse, A.G.E. (1961) Histochemistry; Theoretical and Applied, 2nd edn. Churchill, London.

Peterson, R.N. \& Freund, M. (1970) Profile of glycolytic enzyme activities in human spermatozoa. Fert. Steril. 21, 151-157.

Rao, S.S., Sheth, A.R. \& Phadke, A.M. (1959) A preliminary note on the succinic dehydrogenase activity of human semen. Ind. J. med. Sci. 13, 302-304.

Sidhu, K.S. \& Guraya, S.S. (1978) Effect of cold shock on enzyme release in buffalo (Bubalus bubalis) spermatozoa. Annls Biol. anim. Biochim. Biophys. 18, 283-286.

Singh, B. \& Sandhu, D.P. (1972) Activities of lactic and succinic dehydrogenase of cattle and buffalo spermatozoa. J. Dairy Sci. 25, 91-96.

Slein, M.W., Cori, G.T. \& Cori, C.F. (1950) A comparative study of hexokinase from yeast and animal tissue. J. biol. Chem. 186, 763-780.

Storey, B.T. \& Kayne, F.J. (1975) Energy metabolism of spermatozoa. V. The Embden-Meyerhof pathway of glycolysis, activities of pathway enzymes in hypotonically treated rabbit epididymal spermatozoa. Fert. Steril. 26, 1257-1265.

Walker, D.G. (1966) The nature and function of hexokinases in animal tissues. In Essays in Biochemistry, Vol. 2, pp. 33-40. Eds P. C. N. Campbell \& G. D. Greville. Academic Press, London.

Wu, S.H., Mckenzie, E.F., Fang, S.C. \& Butts, J.S. (1959) Pathways of glucose utilization in epididymal and testicular sperm cell. J. Dairy Sci. 42, 110 115. 